University of Nebraska - Lincoln

DigitalCommons@University of Nebraska - Lincoln

USDA National Wildlife Research Center - Staff Publications
U.S. Department of Agriculture: Animal and Plant Health Inspection Service

April 2007

\title{
Nicarbazin OvoControl G Bait Reduces Hatchability of Eggs Laid by Resident Canada Geese in Oregon
}

\author{
Kimberly Bynum \\ United States Department of Agriculture, Animal and Plant Health Inspection Service, Wildlife Services, \\ National Wildlife Research Center \\ John D. Eisemann \\ USDA/APHIS/WS National Wildlife Research Center, John.D.Eisemann@aphis.usda.gov \\ Gary C. Weaver \\ United States Department of Agriculture, Animal and Plant Health Inspection Service, Wildlife Services \\ Christi A. Yoder \\ United States Department of Agriculture, Animal and Plant Health Inspection Service, Wildlife Services, \\ National Wildlife Research Center \\ Kathleen A. Fagerstone \\ United States Department of Agriculture, Animal and Plant Health Inspection Service, Wildlife Services, \\ National Wildlife Research Center \\ See next page for additional authors \\ Follow this and additional works at: https://digitalcommons.unl.edu/icwdm_usdanwrc \\ Part of the Environmental Sciences Commons
}

Bynum, Kimberly; Eisemann, John D.; Weaver, Gary C.; Yoder, Christi A.; Fagerstone, Kathleen A.; and Miller, Lowell A., "Nicarbazin OvoControl G Bait Reduces Hatchability of Eggs Laid by Resident Canada Geese in Oregon" (2007). USDA National Wildlife Research Center - Staff Publications. 621.

https://digitalcommons.unl.edu/icwdm_usdanwrc/621

This Article is brought to you for free and open access by the U.S. Department of Agriculture: Animal and Plant Health Inspection Service at DigitalCommons@University of Nebraska - Lincoln. It has been accepted for inclusion in USDA National Wildlife Research Center - Staff Publications by an authorized administrator of DigitalCommons@University of Nebraska - Lincoln. 
Authors

Kimberly Bynum, John D. Eisemann, Gary C. Weaver, Christi A. Yoder, Kathleen A. Fagerstone, and Lowell A. Miller 


\title{
Nicarbazin OvoControl G Bait Reduces Hatchability of Eggs Laid by Resident Canada Geese in Oregon
}

KIMBERLY S. BYNUM, ${ }^{\mathbf{1}}$ Product Development Research Program, United States Department of Agriculture, Animal and Plant Health Inspection Service, Wildlife Services, National Wildlife Research Center, 4101 LaPorte Avenue, Fort Collins, CO 80521, USA

JOHN D. EISEMANN, Product Development Research Program, United States Department of Agriculture, Animal and Plant Health Inspection Service, Wildlife Services, National Wildlife Research Center, 4101 LaPorte Avenue, Fort Collins, CO 80521, USA

GARY C. WEAVER, ${ }^{2}$ United States Department of Agriculture, Animal and Plant Health Inspection Service, Wildlife Services, 6135 NE 80 th Avenue, Suite A8, Portland, OR 97218, USA

CHRISTI A. YODER, Product Development Research Program, United States Department of Agriculture, Animal and Plant Health Inspection Service, Wildlife Services, National Wildlife Research Center, 4101 LaPorte Avenue, Fort Collins, CO 80521, USA

KATHLEEN A. FAGERSTONE, Product Development Research Program, United States Department of Agriculture, Animal and Plant Health Inspection Service, Wildlife Services, National Wildife Research Center, 4101 LaPorte Avenue, Fort Collins, CO 80521, USA

LOWELL A. MILLER, Product Development Research Program, United States Department of Agriculture, Animal and Plant Health Inspection Service, Wildlife Services, National Wildlife Research Center, 4101 LaPorte Avenue, Fort Collins, CO 80521, USA

\begin{abstract}
Expanding populations of resident Canada geese (Branta canadensis) are resulting in increased conflicts with humans. Nonlethal and humane means are needed for managing Canada goose flocks at a variety of sites, including golf courses, industrial parks, government sites, and city parks. Decreased egg production and hatching are side effects of nicarbazin, a veterinary drug used to treat coccidiosis in chickens. Capitalizing on these effects, we developed nicarbazin as a reproductive inhibitor for Canada geese and conducted a field efficacy study. We recruited study sites in 2002 and 2003. Following laboratory testing, we conducted a field efficacy trial of nicarbazin for reducing the hatchability of Canada goose eggs in spring 2004 in Oregon, USA. The study began in February 2004 at 10 sites in Oregon, with 2 control and 3 treated sites on each side of the Cascades. We fed bait daily to resident Canada geese for approximately 6 weeks. We located and monitored nests until hatching or $\geq 5$ days beyond the expected hatching date to determine hatchability. We completed data collection in May 2004. Geese consumed 8,000 kg of bait, with 5,100 kg of OvoControl G (Innolytics, LLC, Rancho Santa Fe, CA) 2,500-ppm nicarbazin bait consumed among 6 treated sites and 2,900 kg of untreated bait consumed among 4 control sites. We monitored 63 nests at treated sites and 46 nests at control sites to determine hatching success of eggs. There was a $62 \%$ reduction in the percentage of nests with $100 \%$ hatchability at treated sites as compared to controls. There was a $93 \%$ increase in the percentage of nests at treated sites with $0 \%$ hatchability as compared to nests with no eggs hatching at control sites. Hatchability from treated sites versus control sites was reduced $36 \%(F=5.72, P=0.0622)$. We submitted results from this study to support Environmental Protection Agency registration of nicarbazin as a reproductive inhibitor for use in Canada geese. We have shown that treatment of resident Canada geese with OvoControl G 2,500-ppm nicarbazin bait by licensed, trained applicators immediately prior to and during the breeding season can reduce hatchability of eggs laid by treated geese, thereby reducing recruitment of goslings into problem resident Canada goose populations. (JOURNAL OF WILDLIFE MANAGEMENT 71(1):135-143; 2007)
\end{abstract}

DOI: $10.2193 .2005-603$

KEY WORDS avian contraception, avian population control, Canada geese, hatchability control, nicarbazin, OvoControl G.

Resident Canada goose (Branta canadensis) populations are rapidly growing across the United States, causing increasingly frequent conflicts with humans (Conover and Chasko 1985, Chasko and Conover 1988, Gosser et al. 1997, United States Department of the Interior 2005). Although many communities want reductions in resident goose populations, they often do not consider lethal control alone as acceptable. Kokel (2004) reports that of comments received on the 2002 Draft Environmental Impact Statement on resident Canada goose management, $56 \%$ of comments from private individuals supported only nonlethal control and management alternatives. Some areas have used reproductive control methods as a tool for managing resident Canada goose populations (Addison and Amernic 1983, Wright and Phillips 1991, Smith 1995). However, current methods require locating individual goose nests to allow coating the eggs with oil (egg oiling; Cummings et al. 1997), shaking eggs (egg addling), or puncturing eggs to prevent them from

1 E-mail: kbynum@earthlink.net

${ }^{2}$ Deceased hatching. In Minnesota, USA, destruction of each egg cost an estimated $\$ 6.38$ when labor, equipment, and travel expenses were included (Cooper and Keefe 1997). Many nests cannot be found by resource managers in urban settings, particularly when nests are spread over private properties, where access must be granted by each owner (United States Department of the Interior 2005). Development of contraceptive bait that could be fed to resident Canada geese at central locations in nesting areas would allow simultaneous treatment of many nests, even when spread across different properties.

Nicarbazin is a 1:1 equimolar crystalline complex of 4,4'dinitrocarbanilide (CAS no. 330-95-0) and 2-hydroxy-6,6dimethylpyrimidine (CAS no. 108-79-2). Nicarbazin has been registered with the Food and Drug Administration (FDA) since 1955 to treat broiler chickens for coccidiosis, a disease characterized by weight loss and diarrhea due to intestinal protozoa. When laying or breeding hens ingest nicarbazin, it causes reductions in egg laying and hatchability (Jones et al. 1990, Hughes et al. 1991, Johnston et al. 2001). Jones et al. (1990) demonstrated that diets containing 
25-100 ppm nicarbazin reduced egg hatchability in chickens (Gallus domesticus) by treatment days 6-10, with $100 \mathrm{ppm}$ nicarbazin reducing hatchability to $<1 \%$. Hughes et al. (1991) reported a reduction in hatchability from $93.3 \%$ to $31 \%$ by days $10-11$ when they treated hens with $50 \mathrm{ppm}$ nicarbazin for 4 days. Johnston et al. (2001) showed that treatment of chickens with $147 \mathrm{ppm}$ nicarbazin significantly reduced the reproductive rate through reductions in both egg hatching and egg laying. Based on these studies, we investigated nicarbazin as a potential agent that could induce reproductive inhibition for pest avian species.

We made numerous attempts to develop bait to deliver adequate contraceptive doses of nicarbazin to Canada geese in the field. Ultimately, Bynum et al. developed a palatable nicarbazin bait, OvoControl $G^{\circledast}$ (K. S. Bynum, United States Department of Agriculture, Animal and Plant Health Inspection Service, Wildlife Services [USDA/APHIS/WS/ NWRC], National Wildlife Research Center, unpublished data). Following studies of laboratory palatability and nicarbazin absorption, we tested bait in the field to assess the efficacy of nicarbazin for reproductive inhibition in Canada geese. We investigated whether the 2,500-ppm nicarbazin bait OvoControl G (Innolytics, LLC, Rancho Santa Fe, CA) suppressed the hatchability of Canada goose eggs under field conditions in Oregon, USA.

\section{STUDY AREA}

An initial request for USDA/APHIS/WS Operations collaborators resulted in positive responses from several states, from which we selected Oregon as the study location. We presented background and study information to managers at each of 21 potential sites, and managers then decided whether to volunteer their site for the study. Budget constraints limited the study to 10 sites, with 5 sites on each side of the Cascades. Of the total 15 sites that volunteered to participate in the study, we selected 10 sites based on location, number of potential breeding pairs based on verbal history, and suitability for study procedures. Sites signed Agreements for Control with Oregon Wildlife Services before onset of the study.

We selected study sites to allow 2 control and 3 treated sites on each side of the Cascades, maximizing treated sites for study analysis. This allowed testing of OvoControl $G$ in 2 very different environments in terms of climate and precipitation. Sites east of the Cascades were relatively dry and sparsely vegetated. Sites west of the Cascades received more precipitation and had more vegetation. Study sites were located in Multnomah, Deschutes, Jefferson, Lake, Washington, Wasco, Lane, Linn, and Columbia counties in Oregon and included corporate office complexes, city and state parks, private industrial ponds, port and harbor areas, and managed communities.

Site HI (western control site) was a 2- to 4-ha site located in Portland, with the Columbia River on the north side and a small bay and marina to the south. A long, narrow strip (9-14 $\mathrm{m}$ wide and $180 \mathrm{~m}$ long) on top of the island served as a feeding area for Canada geese. There were 26 willow
(Salix spp.) trees on the island, as well as 30-35\% coverage of the island by blackberry (Rubus spp.) bushes that were approximately $1.2 \mathrm{~m}$ high. Rocks about $10-15 \mathrm{~cm}$ in diameter covered the island shoreline. There were 35 geese on average at the site, with most of the flock forming pairs by mid-February.

Site TR (western control site) was located near the Columbia River and the town of Scappoose and comprised approximately 2.5 ha with 2 ponds. The south pond had a more manicured shoreline and appeared to have more geese. Feeding areas included small lawn grass areas bordered by water or trees. The south pond also had better nesting habitat in the form of an approximately 0.3-ha island in the pond that had about $85 \%$ cover with tall grasses and a few trees. There were about 20 Canada geese present.

Site NH (western treated site) was a large site in Beaverton and comprised a large landscaped pond in a central courtyard of office buildings, athletic fields, facilities, walking and running trails, and wetland areas on 2 sides of the property. Wetland areas consisted of an irrigation and drainage aqueduct and a stream running through grassy areas with cattails (Typha spp.). Geese fed on the grassy areas surrounding the pond and in the wetlands, and they nested in the concrete planters around the pond and grassy areas in the wetlands. There had previously been about 12 breeding pairs at site $\mathrm{NH}$ each year.

Site SB (western treated site) was near the city of Florence and was an estuarine site where the Siusilaw River opened in to Alsea Bay. Water depth fluctuated between about $9 \mathrm{~m}$ to about $0.3 \mathrm{~m}$, depending on the time of day and the tide. The shoreline and islands at the site were vegetated with grasses that served as both feeding and nesting areas for Canada geese. When the tide was out, the islands were soft mud and sand that composed a target site area of about $19 \mathrm{~m}^{2}$. Grassy areas had about $10 \%$ cover of about $0.6 \mathrm{~m}$ in height, and access was only by boat. There were about 40 Canada geese at the site, and additional geese often loafed at the site.

Site $\mathrm{MB}$ (western treated site) comprised 2 locations near the town of Sweet Home. There were 2 gravel pit ponds accessible for the study immediately surrounded by native grass areas and agricultural fields of grain and grasses, including rye (Secale spp.), wheat (Triticum spp.), and fescue grass (Festuca spp.) beyond the native grass borders. Managers considered agricultural damage due to the Canada geese a significant problem in the area. Canada geese fed in grass areas, as well as in agricultural fields, and nested on the shores of the ponds and on islands in the middle of the ponds. At least 40 Canada geese routinely utilized the site.

Site CP (eastern control site) was located on Lake Billychinook and consisted of a large reservoir with at least 3 islands on which the Canada geese nested. Grass lawn areas surrounded the day-use and picnic areas, and they served as feeding ground for Canada geese. Geese also nested at the base of rocky cliffs that surrounded about $75 \%$ of the lake. Oregon Wildlife Services removed about 80 of $300+$ Canada geese from the area in June of 2000. We observed at least 40 Canada geese at the site routinely. 
Site CV (eastern control site) was a lake associated with the city golf course in Christmas Valley. The site included a lake of approximately $6,500 \mathrm{~m}^{2}$ with a depth of about 1-2 $\mathrm{m}$, surrounded by brush, bunch grasses, and weeds or forbs. The local golf course had manicured lawns and greens that served as feeding and loafing areas for the geese during the breeding season. Prior to the breeding season, geese typically fed on hay fields located outside the town. The main nesting area was on an island in the lake, also covered with brush. There were approximately 400 Canada geese routinely observed at the site.

Site PP (eastern treated site) was a series of city parks located along the Deschutes River in the city of Bend. The Deschutes River was approximately $24 \mathrm{~m}$ wide and $2.5 \mathrm{~m}$ deep around the study site and had shoreline vegetation including park lawn grass, high desert shrubs, sedges (Carex spp.), and alder (Alnus spp.), willow, conifer, and pine (Pinus spp.) trees. The feeding areas consisted of park lawn that had sidewalks and roadway boundaries. Nesting areas included islands in the Deschutes River, cliffs on the west bank of the river, and around and within abandoned mill buildings in the Old Mill District. Approximately 50-100 Canada geese routinely used the site.

Site DS (eastern treated site) comprised 2 areas located near the town of The Dalles at the confluence of the Columbia and Deschutes rivers. The river in the site area was about $400 \mathrm{~m}$ wide and had a depth of about $5 \mathrm{~m}$ in the study areas. Alder, willows, blackberry bushes, pine, spruce (Picea spp.), and reeds (Phragmites spp.) bordered the river. Areas of canary grass (Phalaris canariensis) also bordered the river. Site DS was a camping and day-use area along the river that had manicured grass areas for the geese to feed on. Nesting areas consisted primarily of islands in the Deschutes River and the banks of the river, most of which had to be accessed by boat. Nesting islands had about $90 \%$ cover consisting of dense shrubs on rock with sandy/loam edges. Some of the islands, however, had no cover at all. About 2535 Canada geese visited the site often.

Site BB (eastern treated site) was a recreational and residential community located in the Deschutes National Forest in Oregon. We later dropped this site from the study because of missing records. The community comprised about 740 ha and included a series of about 13 lakes and ponds, 2 golf courses, and several natural areas, all of which provided excellent habitat for resident Canada geese. Nesting areas included islands in the ponds and the natural areas where tall prairie grasses provided natural cover. There were $\geq 200$ resident Canada geese on the property.

\section{METHODS}

The USDA/APHIS/WS/NWRC Institutional Animal Care and Use Committee and the United States Environmental Protection Agency (EPA) approved this study (QA1102) prior to initiation. We conducted this study under Good Laboratory Practices guidelines for submission to the EPA to support registration of OvoControl $G$ as a reproductive inhibitor for resident Canada geese.
We excluded an eastern treated site from the study because of missing records, and we excluded all data from this site from analysis. It was unclear if personnel lost data records or if personnel did not properly collect and record all required data. Missing records included study site maps, bait station locations, nest locations, balance calibration records, and nontarget species videotapes. We decided to exclude the site from analysis, as we could not verify the data.

\section{Determination of Flock Size to Allow Treatment Group Assignment}

Field personnel conducted 3 initial flock counts at all study sites (2 morning counts and one evening count) on 15 and 16 February 2004 to allow random assignment of flocks to treatment groups. We did not mark the Canada geese in any way to keep the study as similar to actual conditions of use in the field as possible, as requested by the EPA. Field personnel made a systematic count of adult Canada geese as they walked through the site, trying to avoid doublecounting individuals. We randomly assigned the 2 largest flocks on the same side of the Cascades as treated or control by flipping a coin. We randomly assigned the remaining 3 flocks on that side of the Cascades by drawing one of the 3 from a hat, with the one drawn assigned as control and the other 2 as treated.

\section{Initial Flock Counts and Site Treatment Group Assignments}

West of the Cascades, we assigned the 2 largest flocks of 39 and 41 adult Canada geese to control and treated groups, respectively. We assigned average western flocks of 22 and 26 adult Canada geese as treated sites and assigned a flock of 35 adult Canada geese as the other control site. East of the Cascades, we assigned the 2 largest flocks of 373 and 116 adult Canada geese to control and treated groups, respectively. We assigned average eastern flocks of 65 and 55 (site excluded from study) adult Canada geese as treated sites and assigned a flock of 3 adult Canada geese as the other control site. We decided to include the flock of 3 adult Canada geese because poor weather conditions at the site on 15 and 16 February 2004 reduced the number of resident geese normally present.

\section{Test Bait}

We used OvoControl G bait for this study. OvoControl G is a semisoft, wheat-based bread bait containing 2,500 ppm nicarbazin augmented with propylene glycol to enhance texture and fishmeal to improve palatability. The target consumption rate of $\geq 25$ grams per Canada goose would provide $\geq 62.5 \mathrm{mg}$ nicarbazin, which is $\geq 15.625 \mathrm{mg} / \mathrm{kg}$ nicarbazin for a 4-kg Canada goose. We produced control baits in the same manner as OvoControl $G$ without adding nicarbazin, but they differed physically from OvoControl $G$ in that size was more variable and the color was a lighter yellow. OvoControl G 2,500-ppm nicarbazin bait was manufactured in 5 batches, which were pooled and mixed prior to packaging in sealed plastic pails. We collected pretreatment samples of each of 5 batches before pooling. 
We performed poststudy analysis of bait using samples collected from pails at the end of the study from each site. Exygen Research (State College, PA) analyzed baits to assess nicarbazin content before and after treatment to assess nicarbazin levels in pre- and poststudy samples.

\section{Bait Analysis}

Results of bait nicarbazin analyses prior to study onset showed batch 1 contained 2,580 ppm, batch 2 contained 2,566 ppm, batch 3 contained 2,288 ppm, batch 4 contained 2,350 ppm, and batch 5 contained 2,613 ppm. Batches prior to study onset averaged 2,479 $\mathrm{ppm}$ nicarbazin, $99.2 \%$ of the label specification for 2,500 ppm nicarbazin (OvoControl G). Posttreatment samples from treated sites had 2,395 ppm, 2,464 ppm, 2,504 ppm, 2,364 ppm, and 2,472 ppm nicarbazin, with an average 2,440 $\mathrm{ppm}$ nicarbazin in treated bait $(97.6 \%$ of the label specification for $2,500 \mathrm{ppm}$ nicarbazin [OvoControl G]). No control bait samples had detectable levels of nicarbazin either in pretreatment or posttreatment analyses.

\section{Baiting Strategy}

We approximated the time when we anticipated the Canada geese to lay the first substantial number of eggs at each site based on historical accounts of goslings on the site. We timed the onset of acclimation to allow the acclimation period of $\geq 14$ days to end and the 42 -day treatment to begin 14 days prior to when we expected the first substantial number of eggs. Field personnel began developing a baiting strategy approximately 14 days before the treatment period began. We administered test bait via free-choice feeding from bait stations (black rubber feed pans) into which we placed bait at dawn and removed it at dusk. We provided bait to field personnel in letter-, number- and color-coded containers to maintain blinding to treatment assignments. During the first 7 days of acclimation, we scattered the assigned bait or whole corn around bait stations to entice Canada geese to approach feed pans and consume bait.

We arranged bait stations such that personnel could visit the entire site in a systematic manner to conduct flock counts that minimized risk of duplicate counts. We provided multiple bait stations (9-24) at each site to minimize territory and bait-defending behavior exhibited by dominant geese. Bait stations were $\geq 7.6 \mathrm{~m}$ apart, with stations dispersed over the site at 8 of 10 sites and stations placed in a line on manicured grass at the remaining 2 sites.

\section{Determination of Bait Consumption}

We measured the preweighed bait provided at each station and weighed any bait remaining at dusk to determine bait consumption at each site. We based the initial amount of bait offered on flock counts at the site, offering $50 \mathrm{~g}$ of bait per goose on the site during the acclimation period. We calculated the amounts of bait offered during treatment based on the amount of uneaten bait retrieved from the previous feeding, such that we added an excess $500-750 \mathrm{~g}$ of bait to the amount of bait consumed the previous day. In cases where we filled bait pans to capacity and the geese still consumed all bait, we continued to fill pans, but did not add another pan.

We included a sentinel bait station at each site, which had metal mesh screening over it to block access to the bait. We applied bait in sentinel stations (typically $100 \mathrm{~g}$ ) and removed it on the same schedule as the other bait stations at the site. We used the weight change of sentinel bait to account for variation in weight attributable to moisture accumulation or loss, soiling of the bait, etc. Final calculations of bait consumption included mathematical corrections as a percentage gained or lost as determined by weight change in sentinel bait.

\section{Flock Counts}

We counted adult Canada geese each morning to crudely estimate the number of geese that potentially consumed bait each day. Once we applied bait at all bait stations, field personnel recorded the number of geese around each station, trying to avoid double-counting individual geese. We rounded up flock count numbers and standard errors to represent the next whole goose. During and after flock counts, we observed Canada geese in an attempt to assess overall flock health and behavior during the study. Observations included reproductive behaviors (pairing geese, triumph ceremonies, territory defense, nest construction, breeding, etc.), visually abnormal health (poor body condition, poor feather condition, lack of grooming, unwillingness to move especially in response to human approach, unthrifty, injured birds, etc.), or potentially confounding events (animals other than geese consuming the bait; predators, loose dogs, dead animals in vicinity; adverse environmental conditions, flooding; food supply changes, etc.).

\section{Collection of Reproduction Activity Data}

We began monitoring nest locations at the start of treatment by having field personnel perform systematic sweeps of the site, typically around bodies of water from shoreline to about 15-20 m from shore. We placed flagging near, but not at, the nest approximately 2-3 $\mathrm{m}$ from the nest in branches or weeds, to help avoid attracting predators. We marked monitored nests with fluorescent green flag stakes or flagging tape. We marked non-monitored nests, as determined by the exclusion criteria below, with fluorescent orange flag stakes or flagging tape.

We made the decision to exclude some nests from monitoring due to the lag between nicarbazin ingestion and achievement of effective egg 4,4'-dinitrocarbanilide (DNC) levels. Deposition of lipids and cholesterol into the egg yolk occurs primarily during the rapid follicular growth phase 6-11 days prior to ovulation in domestic fowl, ducks, and pigeons (Johnson 2000) or 10-13 days prior to ovulation in cackling Canada geese (B. c. minima; Raveling 1978), which is also when the majority of DNC incorporates into the yolk. Treatment of chickens with nicarbazin showed that treatment for 6 days is required before consistent levels of egg DNC are reached (Furusawa 2001), and treatment for 8-10 days is required to reach maximum DNC levels in 
Table 1. Average morning flock count of adult Canada geese, average amount of bait treated with OvoControl G ${ }^{\varpi}$ (Innolytics, LLC, Rancho Santa Fe, CA) consumed per site, and average percent hatchability per clutch of eggs of known fate in a field study of OvoControl G in Canada geese in Oregon, USA, 15 February-19 May 2004.

\begin{tabular}{|c|c|c|c|c|c|c|c|c|c|c|}
\hline \multirow[b]{2}{*}{ Area $^{a}$} & \multirow[b]{2}{*}{ Site } & \multirow[b]{2}{*}{ Treatment } & \multicolumn{2}{|c|}{$\begin{array}{l}\text { Average morning flock } \\
\text { count of adult Canada geese }\end{array}$} & \multicolumn{2}{|c|}{$\begin{array}{c}\text { Average bait } \\
\text { consumed/site }(\mathrm{kg})\end{array}$} & \multicolumn{2}{|c|}{ Average clutch size ${ }^{b}$} & \multicolumn{2}{|c|}{$\begin{array}{l}\text { Average } \% \text { hatchability/ } \\
\text { clutch of eggs of known fate }\end{array}$} \\
\hline & & & Average & $\mathrm{SE}$ & Average & $\mathrm{SE}$ & Average & $\mathrm{SE}$ & Average & SE \\
\hline \multirow[t]{5}{*}{ Western sites } & $\mathrm{HI}$ & Control & 40 & 3 & 16.9 & 1.3 & 6 & 1 & 83.26 & 7.93 \\
\hline & TR & Control & 26 & 2 & 11.7 & 0.9 & 5 & 1 & 93.57 & 4.19 \\
\hline & $\mathrm{NH}$ & Treated & 18 & 2 & 3.1 & 0.3 & 6 & 2 & 43.45 & 19.70 \\
\hline & $\mathrm{SB}$ & Treated & 24 & 2 & 1.1 & 0.1 & 7 & 1 & 91.67 & 4.35 \\
\hline & $\mathrm{MB}$ & Treated & 25 & 4 & 4.7 & 0.3 & 7 & 1 & 32.94 & 12.63 \\
\hline \multirow[t]{4}{*}{ Eastern sites } & $\mathrm{CV}$ & Control & 61 & 14 & 8.5 & 0.6 & 6 & 1 & 92.32 & 2.96 \\
\hline & $\mathrm{CP}$ & Control & 7 & 2 & 3.2 & 0.2 & 8 & 1 & 95.24 & 4.76 \\
\hline & $\mathrm{PP}$ & Treated & 94 & 5 & 27.7 & 1.0 & 6 & 1 & 48.97 & 8.17 \\
\hline & DS & Treated & 51 & 5 & 15.9 & 0.7 & 5 & 1 & 54.39 & 7.54 \\
\hline
\end{tabular}

${ }^{a}$ Western sites were study sites west of the Cascades, eastern sites were study sites east of the Cascades.

${ }^{b}$ We rounded up average numbers and standard errors of geese and eggs to the next whole number to represent a whole goose or egg.

the egg (Jones et al. 1990). We did not expect effects on eggs laid by nesting Canada geese until at least day 10 of dosing when combining the 4-6 days required to achieve high plasma DNC levels (Yoder et al. 2005) and the minimum 6 days prior to ovulation when the egg is forming. Including nests with eggs laid before day 10 of treatment would have skewed hatchability data due to this effect. Because the purpose of this study was to determine the effect of OvoControl G nicarbazin bait on hatchability in the field, we did not include nests with eggs found prior to day 10 of treatment and nests in which egg-laying was not completed by 10 days after the end of treatment in hatchability data.

Field personnel counted the number of eggs per clutch and the number of eggs that hatched per clutch daily, which provided hatchability data to evaluate the effectiveness of nicarbazin. We included only data for eggs of known fate, defined as eggs monitored from laying until hatching or 5 days beyond hatching, in calculations of hatchability to ensure that we accounted for losses to predation, rolling from nest, etc. The final determination of effectiveness was the percent reduction in hatchability between treated flocks and control flocks. We calculated percent reduction in hatchability with the following formula: percent reduction in hatchability $=[($ average control percent hatchability average treated percent hatchability)/(average control percent hatchability) $] \times 100$.

\section{Nontarget Species Monitoring}

We used video cameras to record nontarget species at or near bait stations and to monitor whether they consumed bait. We conducted video monitoring every third day at each site during baiting from the time we offered bait until the time we retrieved the bait. We viewed videotapes at the conclusion of the study and recorded observations including species, time spent at bait station, time spent apparently feeding on bait, and the time of day visitation occurred. We assumed that animals observed lowering their heads into bait pans and then raising them repeatedly were consuming bait.

\section{Flock Health and Necropsies}

During treatment, we recorded flock counts and observations of general health, injury, and unusual behaviors or circumstances. If field personnel discovered an ill or injured bird, we consulted the supervising veterinarian and addressed the situation under his direction. We recorded all available information about the illness or injury. We attempted to recover any birds found dead during the course of normal site monitoring. The Oregon State University Veterinary Diagnostic Laboratory conducted routine postmortem examinations on animals found dead at study sites unless decay or scavenging precluded the likelihood of determination of the cause of death. We disposed of carcasses in accordance with local regulations.

\section{Statistical Analysis}

Individual study sites were the experimental unit for the study. The null hypothesis was that there would be no difference in the percentage of eggs hatched per site between treated and untreated sites. We statistically evaluated data on the percent hatchability via general linear model (GLM), with treatment (test or control) and geographic region as fixed effects, and flocks within geographic regions as a random effect, including all interactions of the 2 fixed effects. We pooled residual site variation ( $2 \mathrm{df}$ ) with the inter-clutch variation in the analysis of variance model for estimation of random error. We also evaluated data on flock size with the GLM. We calculated Pearson correlations to assess relationships between study variables. We indicated statistical significance by $P \leq 0.05$. We conducted all statistical analyses using commercially available software, including SAS (Version 9.1; SAS Institute, Cary, NC) and SPSS (Base 8.0; SPSS, Chicago, IL).

\section{RESULTS}

\section{Morning Flock Counts}

During the acclimation and treatment periods, control flocks had an average of $28 \pm 3$ adults and treated flocks had an average of $37 \pm 2$ adults (Table 1). At western sites, control flocks included an average of $31 \pm 2$ adults, whereas 
Table 2. Total number of nests, total number of nests of known fate, total number of eggs, total number of eggs of known fate, total number of eggs of known fate hatched, and percent hatchability of eggs of known fate in a field study of OvoControl G ${ }^{\circledast}$ (Innolytics, LLC, Rancho Santa Fe, CA) in Canada geese in Oregon, USA, 15 February-19 May 2004.

\begin{tabular}{|c|c|c|c|c|c|c|c|c|}
\hline Area $^{a}$ & Site & $\begin{array}{c}\text { Treatment } \\
\text { group }\end{array}$ & $\begin{array}{c}\text { Total no. } \\
\text { nests }\end{array}$ & $\begin{array}{l}\text { Total no. nests } \\
\text { of known fate }\end{array}$ & $\begin{array}{c}\text { Total } \\
\text { no. eggs }\end{array}$ & $\begin{array}{l}\text { Total no. eggs } \\
\text { of known fate }\end{array}$ & $\begin{array}{l}\text { Total no. } \\
\text { eggs of known } \\
\text { fate hatched }\end{array}$ & $\begin{array}{l}\text { Hatchability } \\
\text { of eggs of } \\
\text { known fate }{ }^{b}\end{array}$ \\
\hline \multirow[t]{6}{*}{ Western sites } & $\mathrm{HI}$ & Control & 24 & 13 & 101 & 69 & 50 & $72.5 \%$ \\
\hline & TR & Control & 15 & 7 & 72 & 35 & 32 & $91.4 \%$ \\
\hline & $\mathrm{NH}$ & Treated & 8 & 6 & 42 & 35 & 17 & $48.6 \%$ \\
\hline & $\mathrm{MB}$ & Treated & 30 & 12 & 122 & 77 & 26 & $33.8 \%$ \\
\hline & SB & Treated & 21 & 11 & 134 & 71 & 65 & $91.5 \%$ \\
\hline & $\mathrm{CV}$ & Control & 38 & 23 & 178 & 131 & 120 & $91.6 \%$ \\
\hline \multirow{3}{*}{ Eastern sites } & $\mathrm{CP}$ & Control & 3 & 3 & 22 & 22 & 21 & $95.5 \%$ \\
\hline & $\mathrm{PP}$ & Treated & 43 & 23 & 192 & 130 & 68 & $52.3 \%$ \\
\hline & DS & Treated & 22 & 11 & 85 & 54 & 29 & $53.7 \%$ \\
\hline
\end{tabular}

${ }^{a}$ Western sites were study sites west of the Cascades, eastern sites were study sites east of the Cascades.

b Nest and eggs of known fate are eggs that were monitored from time of egg laying until hatching, loss, or until 5 days beyond the expected hatching date.

treated flocks had $21 \pm 1$ adults (Table 1). At eastern sites, control flocks had an average of $24 \pm 5$ adults, whereas treated flocks included an average of $63 \pm 3$ adults (Table $1)$. There was no significant difference in flock sizes regardless of geographic area $(F=2.94, P=0.1468)$, treatment $(F=0.79, P=0.4139)$, or area by treatment $(F=$ $2.55, P=0.1709)$. We rounded up average numbers of geese and standard errors to the next whole number to represent a whole goose.

\section{Bait Consumption}

Calculation of bait consumed included correction by percent weight lost or gained by bait in the sentinel bait station at each site. Approximately $8,000 \mathrm{~kg}$ of bait were consumed, with $5,100 \mathrm{~kg}$ of nicarbazin bait consumed among 6 treated sites and 2,900 $\mathrm{kg}$ of untreated bait consumed among 4 control sites. At western sites, average daily consumption of treated bait was 2,967 $\pm 1,028 \mathrm{~g}$ and of control bait was $14,343 \pm 2,606 \mathrm{~g}$ (Table 1). At eastern sites, average daily consumption of treated bait was 21,822 $\pm 5,917 \mathrm{~g}$ and of control bait was 5,828 $\pm 2,635 \mathrm{~g}$ (Table 1). Consumption of bait was significantly different in area by treatment analyses $(F=20.45, P=0.0063)$.

\section{Hatchability of Eggs of Known Fate}

We monitored 63 nests at treated sites and 46 nests at control sites to determine hatching success of eggs (Table 2). Average percent hatchability by site was reduced $36 \%$ at treated sites compared to controls, but the reduction was not statistically significant $(F=5.72, P=0.062)$. Hatchability ranged from $0 \%$ to $100 \%$ at both treated and control sites (Table 3). Overall, there was a $62 \%$ reduction in the percentage of nests with $100 \%$ hatchability at treated sites as compared to controls. There was a $93 \%$ increase in the percentage of nests at treated sites with $0 \%$ hatchability as compared to nests with no eggs hatching at control sites (Table 3). Nests averaged 7 eggs per clutch, which did not correlate with treatment $(r=0.036, P=0.709$; Table 1$)$. Treated sites had lower percent hatchability correlated with treatment $(r=-0.473, P=0.001)$. Percent hatchability also inversely correlated with the average bait consumption per site at treated sites $(r=-0.207, P=0.031)$.

\section{Nontarget Species Monitoring}

At treated sites, we observed avian and mammalian nontarget species. The most prevalent nontarget avian species observed near bait stations or consuming bait were American crows (Corvus brachyrhynchos), corvids (genus Corvus, indistinguishable between either a common raven [Corvus corax] or American crow), and mallards (Anas platyrhynchos; Table 4). American crows were seen at western treated $\mathrm{MB}$ and $\mathrm{SB}$ sites, where the average time spent at bait stations was 1 minute 27 seconds and average time spent consuming bait was 1 minute 21 seconds (Table 4). Corvids were prevalent at the western treated $\mathrm{MB}$ and eastern treated DS sites, where we observed them at bait stations an average 2 minutes 7 seconds, and they spent 2 minutes 26 seconds consuming bait (Table 4), indicating that corvids consuming bait stayed at the station longer than those visiting stations without consuming bait. When residents at the site, mallards were frequent visitors to the bait stations, where they were at bait stations an average 3

Table 3. Distribution of percentage of nests falling into hatchability categories of $100 \%, 99-75 \%, 74-50 \%, 49-25 \%, 24-1 \%$, and $0 \%$ at control and treated sites in a field study of OvoControl $G^{\circledast}$ (Innolytics, LLC, Rancho Santa Fe, CA) in Canada geese in Oregon, USA, 15 February-19 May 2004.

\begin{tabular}{|c|c|c|c|c|c|c|c|}
\hline Area $^{a}$ & $\begin{array}{l}\text { Total } \\
\text { nests }\end{array}$ & $100 \%$ & $\begin{array}{c}99 \%- \\
75 \%\end{array}$ & $\begin{array}{c}74 \%- \\
50 \%\end{array}$ & $\begin{array}{c}49 \%- \\
25 \%\end{array}$ & $\begin{array}{c}25 \%- \\
1 \%\end{array}$ & $0 \%$ \\
\hline \multicolumn{8}{|l|}{ Overall } \\
\hline Control & 46 & 67.4 & 21.7 & 6.5 & 2.2 & 0 & 2.2 \\
\hline Treated & 63 & 25.4 & 20.6 & 12.7 & 7.9 & 3.2 & 30.2 \\
\hline \multicolumn{8}{|c|}{ Eastern sites } \\
\hline Control & 26 & 69.2 & 23.1 & 3.8 & 3.8 & 0 & 0 \\
\hline Treated & 34 & 14.7 & 26.5 & 14.7 & 11.8 & 5.9 & 26.5 \\
\hline \multicolumn{8}{|c|}{ Western sites } \\
\hline Control & 20 & 65 & 20 & 10 & 0 & 0 & 5 \\
\hline Treated & 29 & 37.9 & 13.8 & 10.3 & 3.4 & 0 & 34.5 \\
\hline
\end{tabular}

${ }^{a}$ Western sites were study sites west of the Cascades, eastern sites were study sites east of the Cascades. 
Table 4. Numbers of nontarget species observed at bait stations, numbers of days on which nontarget species were observed at bait stations, numbers of days on which nontarget species were observed eating bait at bait stations, average time spent at the bait station overall, and average time spent eating bait in a field study of OvoControl G ${ }^{\circledast}$ (Innolytics, LLC, Rancho Santa Fe, CA) in Canada geese in Oregon, USA, 15 February-19 May 2004.

\begin{tabular}{|c|c|c|c|c|c|c|}
\hline Species $^{a}$ & Site & $\begin{array}{l}\text { No. nontargets } \\
\text { observed }\end{array}$ & $\begin{array}{c}\text { No. d } \\
\text { observed at } \\
\text { bait stations }\end{array}$ & $\begin{array}{l}\text { No. d } \\
\text { observed eating } \\
\text { at bait stations }\end{array}$ & $\begin{array}{l}\text { Average time spent } \\
\text { at bait station } \\
\text { (min:sec) }\end{array}$ & $\begin{array}{c}\text { Average time } \\
\text { spent eating bait } \\
\text { (min:sec) }\end{array}$ \\
\hline \multicolumn{7}{|l|}{ Avian species } \\
\hline American crow & $\mathrm{MB}, \mathrm{SB}$ & 158 & 8 & 6 & $01: 27$ & 01:21 \\
\hline American robin & $\mathrm{MB}$ & 15 & 4 & 0 & $00: 54$ & 00:00 \\
\hline \multicolumn{7}{|l|}{ Corvid species } \\
\hline (American crow or raven) & DS, MB & 1,847 & 16 & 16 & 02:07 & $02: 26$ \\
\hline Dark-eyed junco species & $\mathrm{NH}$ & 5 & 4 & 4 & 01:04 & $00: 48$ \\
\hline European starling & $\mathrm{NH}, \mathrm{MB}$ & 5 & 3 & 2 & $01: 17$ & 00:05 \\
\hline Green-tailed towhee & $\mathrm{SB}$ & 10 & 1 & 1 & 01:00 & $00: 34$ \\
\hline Gull & DS & 19 & 1 & 1 & $00: 34$ & $00: 14$ \\
\hline Hybrid duck & $\mathrm{PP}, \mathrm{NH}$ & 24 & 6 & 6 & $02: 35$ & $02: 22$ \\
\hline Hybrid goose & $\mathrm{PP}$ & 2 & 1 & 1 & $04: 52$ & $04: 52$ \\
\hline Mallard & $\mathrm{NH}, \mathrm{PP}, \mathrm{DS}$ & 683 & 27 & 27 & $03: 33$ & 03:07 \\
\hline Ring-necked pheasant & $\mathrm{MB}$ & 1 & 1 & 1 & $00: 54$ & $00: 54$ \\
\hline Rock dove & PP & 2 & 1 & 1 & 01:41 & 00:00 \\
\hline Spotted towhee & $\mathrm{NH}$ & 9 & 4 & 4 & 02:04 & $00: 21$ \\
\hline Swan & $\mathrm{PP}$ & 10 & 5 & 5 & $04: 31$ & $04: 31$ \\
\hline $\begin{array}{l}\text { Unidentified small bird } \\
\text { (sparrows, towhees, etc.) }\end{array}$ & $\mathrm{DS}, \mathrm{SB}, \mathrm{MB}, \mathrm{NH}$ & 77 & 15 & 8 & $14: 17$ & 11:36 \\
\hline \multicolumn{7}{|l|}{ Mammalian species } \\
\hline Dog & $\mathrm{MB}, \mathrm{PP}$ & 31 & 15 & 8 & $00: 34$ & 00:01 \\
\hline Human & $\mathrm{PP}, \mathrm{MB}$ & 9 & 4 & 2 & $11: 33$ & 00:03 \\
\hline Nutria & $\mathrm{NH}$ & 12 & 4 & 3 & $08: 55$ & $08: 54$ \\
\hline Ground squirrel & $\mathrm{DS}, \mathrm{MB}$ & 121 & 11 & 10 & 00:59 & $00: 48$ \\
\hline Tree squirrel & $\mathrm{MB}, \mathrm{SB}, \mathrm{PP}$ & 7 & 3 & 2 & $00: 43$ & $00: 29$ \\
\hline
\end{tabular}

${ }^{a}$ American robin, Turdus migratorius; dark-eyed junco, Junco sp.; European starling, Sturnus vulgaris; green-tailed towhee, Pipilo chlorurus; gull, Larus sp.; ring-necked pheasant, Phasianus colchicus; rock dove, Columbia livia; spotted towhee, Pipilio maculatus; swan, Cygnus sp.; dog, Canis lupus familiaris; nutria, Myocaster coypus.

minutes 33 seconds and consumed bait an average 3 minutes 7 seconds (Table 4).

The most prevalent mammalian nontarget species observed were ground squirrels in the genus Sciurus. We observed ground squirrels at the western treated $\mathrm{MB}$ and eastern treated DS sites, where average time spent at the bait station was 59 seconds and consuming bait was 48 seconds (Table 4). We observed dogs at the western treated MB and eastern treated PP sites, with an average time of 34 seconds spent at bait stations and 1 second spent consuming bait, possibly due to owners calling their dogs away (Table 4). There was minimal human interaction with bait, and humans that did interact typically inspected bait and bait pans or used bait to hand-feed Canada geese at the site. However, we observed 3 humans at a bait station on one day at the western treated MB site and we observed one human consuming bait on one day at the eastern treated PP site, regardless of signs posted to not handle bait pans or feed.

\section{Flock Health and Necropsy}

As observations of flock health are subjective and field personnel were not waterfowl experts or veterinarians, it was difficult to quantify observations of flock health. Occasional notations included lameness and injured or broken wings, both consistent with injuries common to wild Canada geese. We seldom reported illness in observation records, and one incidence of suspected illness resulted in death of the Canada goose, with subsequent necropsy attributing the death to gunshot wound trauma. We did not report any illnesses or deaths attributable to nicarbazin or control bait consumption during the study.

\section{DISCUSSION}

\section{Efficacy of OvoControl G for Reducing Hatchability}

Keefe (1996) estimated that managers must remove approximately 5 eggs to have the effect of preventing one adult from joining the breeding population. In this study, resident Canada geese were treated with OvoControl G 2,500-ppm nicarbazin bait immediately prior to and during the breeding season to study the effects on hatchability of eggs laid by treated geese. Treatment with nicarbazin bait reduced hatchability of eggs laid by resident Canada geese by $36 \%$ and increased the number of nests with no hatching eggs by $93 \%$ as compared to control sites. Results suggest that OvoControl G 2,500-ppm nicarbazin bait could be used as a tool to reduce recruitment of goslings into problem resident Canada goose populations.

Clutch hatchability data from treated sites revealed many nests with $0 \%$ hatchability and several nests with $100 \%$ hatchability. When geese ingested high nicarbazin doses, they likely produced clutches in which no eggs hatched. Other geese on site were likely ingesting little or no 
nicarbazin bait and laid clutches in which all eggs laid hatched. Percent hatchability correlated inversely with average amount of bait consumed at treated sites.

Nicarbazin can completely inhibit egg production in chickens (Jones et al. 1990, Hughes et al. 1991), which may have been a confounding factor in actual reproductive inhibition achieved in resident Canada geese. The magnitude of this effect could not be determined under field conditions in this study, as there was no way to quantify eggs that were not laid. It is possible that treatment reduced the number of females that nested as well as reducing hatchability of eggs laid. If we could have quantified the number of geese that consumed enough bait to suppress egg production, we may have shown an even greater reproductive inhibition in Canada geese than what these data indicate.

This study simulated operational use of nicarbazin, a requirement imposed by regulatory agencies, so we did not mark Canada geese with neck collars or leg bands. We used adult Canada geese flock counts performed each morning to estimate the number of geese that potentially consumed bait each day. Consequently, there was no way to determine which geese were residents and which were migrating birds stopping for morning feeding. Likewise, there was no means of determining how much bait individual geese or animals other than the resident flock consumed throughout the day because we performed counts only in the morning.

\section{Nontarget Hazards of OvoControl G}

A common concern of the public and wildlife professionals is the impact of chemical control methods on nontarget species, particularly threatened and endangered species. Nontarget birds such as crows, ravens, and mallards also approached bait stations and consumed some of the feed intended for the geese. Consumption of bait by nontarget species was somewhat limited by competition with the geese.

Toxicity studies of nicarbazin in mammals showed minimal effects, with toxicological effects in rats at $>10,000 \mathrm{mg} / \mathrm{kg}$ nicarbazin on an acute basis or $>400 \mathrm{mg} /$ $\mathrm{kg}$ nicarbazin on a subacute chronic basis (Roberts et al. 1998). No mammalian reproductive toxicity was observed in rats treated with up to $400 \mathrm{mg} / \mathrm{kg}$, the amount of nicarbazin in $6.25 \mathrm{~kg}$ of OvoControl $\mathrm{G}$ bait, daily through the production of 2 consecutive litters (Roberts et al. 1998). Nicarbazin also has low toxicity to birds. Extrapolating from chicken toxicity data, a crow would have to consume approximately $0.63 \mathrm{~kg}(1.4 \mathrm{lb})$ of OvoControl G bait each day for 84 days before it would have a $50 \%$ chance of dying (Ott et al. 1956, Roberts et al. 1998). The volume of nicarbazin bait that nontarget birds and mammals would have to consume to result in death precluded harm by casual or even regular exposure to nicarbazin baits. Adverse effects noted in animals have generally been observed only after treatment of 1 year or longer (Roberts et al. 1998), which was not possible with only approximately 56 days of baiting during the study.

The timing of baiting and the duration of nicarbazin ingestion required for reproductive effects helps reduce the risk exposure to nicarbazin for many nontarget species because Canada geese typically nest early in the year. We offered OvoControl $G$ nicarbazin bait in February and withdrew it in April. Animals must consume nicarbazin bait for several days to achieve blood levels that affect the hatchability of forming eggs (Yoder et al. 2005). Migrating birds would not likely consume nicarbazin close enough to egg laying or over enough consecutive days to affect their reproduction. Nicarbazin is undetectable in the plasma of Canada geese, mallards, and chickens 4-6 days after consumption of nicarbazin bait has stopped (Yoder et al. 2005). The levels of DNC in the blood reduces by half within 2 days after bait consumption stops (Yoder et al. 2005). If the level of DNC falls by approximately one-half of its peak levels, there will be insufficient DNC to affect the forming eggs. By 2 days after bait consumption has stopped, there are no observable effects on the forming egg (Jones et al. 1990).

During the study, human interaction with bait stations was limited to 2 days at 2 sites. We observed only 1 human consuming bait on 1 day at the eastern treated PP site. No adverse effects occur in children or adults due to nicarbazin bait consumption. The untreated bait is bland tasting and neutral in color and has no particular appeal to humans. Treated bait has a mild astringent quality and would cause a cotton-mouth feeling that would discourage further consumption (L. Clark, USDA/APHIS/WS/NWRC, personal communication).

Nicarbazin is already FDA approved for use in broiler (meat) chickens as a coccidiostat to prevent disease and has undergone rigorous evaluation to assess product use in human food. Nicarbazin is safe in chicken meat at a level of $4 \mathrm{mg} / \mathrm{kg}$ with a human consumption of $500 \mathrm{~g}(1 \mathrm{lb})$ of meat per day by a $60-\mathrm{kg}(120-\mathrm{lb})$ human over a lifetime (United States Department of Health and Human Services 2003). Geese treated with nicarbazin after the spring hunt and well in advance of the fall hunting season are unlikely to be consumed by humans. The FDA recommends a 4-day withdrawal period for treatment of chickens with nicarbazin, and human consumption of treated geese falls well beyond the recommended withdrawal. However, a human could illegally consume a treated goose during or immediately following treatment with nicarbazin bait during the study. Based on calculated lifetime exposures, we do not expect any effect on humans consuming meat with nicarbazin residues, even if meat is consumed before the 4-day withdrawal period.

\section{MANAGEMENT IMPLICATIONS}

Results from this study show that OvoControl G 2,500ppm nicarbazin bait is safe and effective in reducing hatchability of eggs laid by resident Canada geese. Egg oiling, where the egg is coated with corn or mineral oil to prevent development of the embryo and thus to prevent hatching, is a popular method of reproductive control for resident Canada geese (Cummings et al. 1997). However, 
egg oiling requires personnel to locate individual nests to apply treatment. Nicarbazin bait could achieve this level of control through application at known nesting sites for treatment of several breeding pairs at once, without ever locating individual nests. OvoControl G could be considered for incorporation into integrated programs aimed at managing resident flocks.

As a long-lived species with a long breeding life, reproductive control alone is unlikely to result in significant population decreases quickly enough to reduce conflicts between humans and resident Canada geese. Even 95\% reduction in hatchability would result in only a $25 \%$ decrease in the Canada goose population over 10 years (Barnard 1991). Similar to Wright and Phillips (1991), we suggest a potential strategy of lethal control to reduce existing populations, after which reproductive control could be used to help maintain population numbers at a manageable flock size.

\section{ACKNOWLEDGMENTS}

Dedicated in memory of Gary "Charlie" Weaver, 19662006. We thank our dedicated field crew (C. Benedict, A. Betts, D. Bower, J. Brown, T. Fitzhenry, T. Freeman, G. Glaser, N. Jinings, D. Ledbetter, D. Libby, A. Muldoon, P. Ober, E. Olsen, J. Walter, and J. Wick); M. Slater for assistance with site recruitment and study conduct; USDA/ APHIS/WS Oregon State Office and Operations (especially D. Williams, M. Jensen, and C. Rayls) for assistance with study logistics; C. Tope for assistance with study logistics, ordering, personnel issues; and R. Engemann for consulting on statistical analysis.

\section{LITERATURE CITED}

Addison, L. R., and J. Amernic. 1983. An uneasy truce with the Canada goose. International Wildlife 13:12-14.

Barnard, S. 1991. Modeling the Canada goose populations at Great Linford. Game Conservation Annual Review 22:141.

Chasko, G. G., and M. R. Conover. 1988. Too much of a good thing? Living Bird Quarterly 7:8-13.

Conover, M. R., and G. G. Chasko. 1985. Nuisance Canada goose problems in the eastern United States. Wildlife Society Bulletin 13:228233

Cooper, J. A., and T. Keefe. 1997. Urban Canada goose management: policies and procedures. Transactions of the North American Wildlife and Natural Resources Conference 62:412-430.

Cummings, J. L., M. E. Pitzler, P. A. Pochop, H. W. Krupa, T. L. Pugh, and J. A. May. 1997. Field evaluation of white mineral oil to reduce hatching in Canada goose eggs. Proceedings of the Great Plains Wildlife Damage Control Workshop Proceedings 13:67-72.
Furusawa, N. 2001. Transference of dietary veterinary drugs into eggs. Veterinary Research Communications 25:651-662.

Gosser, A. L., M. R. Conover, and T. A. Messmer. 1997. Managing problems caused by urban Canada geese. Berryman Institute Publication 13, Utah State University, Logan, USA.

Hughes, B. L., J. E. Jones, J. E. Toler, J. Solis, and D. J. Castaldo. 1991. Effects of exposing broiler breeders to nicarbazin contaminated feed. Poultry Science 70:476-482.

Johnson, A. L. 2000. Reproduction in the female. Pages 569-596 in G. C. Whittow, editor. Sturkie's avian physiology. Fifth edition. Academic Press, San Diego, California, USA.

Johnston, J. J., W. M. Britton, A. MacDonald, T. M. Primus, M. J. Goodall, C. A. Yoder, L. A. Miller, and K. A. Fagerstone. 2001. Quantification of plasma and egg 4,4'-dinitrocarbanilide (DNC) residues for the efficient development of a nicarbazin-based contraceptive for pest waterfowl. Pest Management Science 58:197-202.

Jones, J. E., J. Solis, B. L. Hughes, D. J. Castaldo, and J. E. Toler. 1990. Reproduction responses of broiler-breeders to anticoccidial agents. Poultry Science 69:27-36.

Keefe, T. 1996. Feasibility study on processing nuisance Canada geese for human consumption. Minnesota Department of Natural Resources, Section of Wildlife, St. Paul, USA.

Kokel, R. W. 2004. Public comments regarding a draft Environmental Impact Statement on resident Canada goose management. Page 141 in $\mathrm{T}$. J. Moser, R. D. Lien, K. C. VerCauteren, K. F. Abraham, D. E. Anderson, J. G. Bruggink, J. M. Coluccy, D. A. Graber, J. O. Leafloor, D. R. Luukkonen, and R. E. Trost, editors. Proceedings of the 2003 International Canada Goose Symposium, 19-21 March 2003, Madison, Wisconsin, USA.

Ott, W. H., S. Kuna, C. C. Porter, and A. C. Cuckler. 1956. Biological studies on nicarbazin, a new anticoccidial agent. Poultry Science 35: 1355-1367.

Raveling, D. G. 1978. The timing of egg laying by northern geese. Auk 95: 294-303.

Roberts, G., and the Joint FAO/WHO Expert Committee on Food Additives (JECFA). 1998. Toxicological evaluation of certain veterinary drug residues in food. WHO Food Additives Series 41:115-122.

Smith, D. W. 1995. A handbook for the control of problem Canada geese. Environment Canada, Canadian Wildlife Service, Pacific Research Centre, Delta, Manitoba, Canada.

United States Department of Health and Human Services, Public Health Service, Food and Drug Administration, Center for Veterinary Medicine. 2003. Guidance document guideline 3. General principles for evaluating the safety of compounds used in food-producing animals. Part IV. Guideline for establishing a tolerance changed to guideline for establishing a safe concentration. Code of Federal Regulations, Title 26, Volume 6, Parts 500-599; Code of Federal Regulations, Title 21, Volume 6. U.S. Department of Health and Human Services, Rockville, Maryland, USA.

United States Department of the Interior. 2005. Final environmental impact statement: resident Canada goose management. U.S. Fish and Wildlife Service, Washington, D.C., USA.

Wright, R. M., and V. E. Phillips. 1991. Reducing the breeding success of Canada and greylag geese, Branta canadensis and Anser anser on gravel pits. Wildfowl 42:42-44.

Yoder, C. A., L. A. Miller, and K. S. Bynum. 2005. Comparison of nicarbazin absorption in chickens, mallards, and Canada geese. Poultry Science 84:1491-1494.

Associate Editor: Ransom 